\title{
PURCHASING MANAGEMENT OF BUSINESS SERVICES IN THE CONTEMPORARY KNOWLEDGE BASED ECONOMY
}

\author{
Corina Pop Sitar ${ }^{1}$
}

\begin{abstract}
Over the last years many countries have turned into real service economies. As a result the strategic importance of purchasing services has increased. This article aims to present the complexity of the process of buying services. The article begins with findings from the literature review regarding the increasing importance of services in the contemporary knowledge based economy. Next, we present the specific characteristics of services which make more difficult the process of buying services. Furthermore, the paper presents the findings from three case studies. At the end of the paper we present the conclusions and the recommandations for managers about how they can improve the purchasing management of services.
\end{abstract}

Keywords: purchasing management, business services, knowledge based economy

JEL Codes: L8, O32

\section{Introduction}

Over the last decades, many countries have turned into real service economies. This shift has affected the structure of the companies and they have been forced to focus more on core activities and to outsource their non-core activities. As a result, the strategic importance of purchasing has increased and professional purchasing of business services has become a crucial factor in gaining a sustainable competitive position.

This paper aims to demonstrate the strategic importance of purchasing management of services into the contemporary knowledge based economy. The paper starts with outlining the importance of buying business services. Next, we present the specific issues of the purchasing process of services compared with the purchasing process of goods based on a literature review. Furthermore, we pointed out how can these specific particularities of business services influence the phases of the purchasing process. The paper presents the empirical results from three focused interviews done in three different organization from Maramures county. At the end of the article we present the conclusions and we elaborate some recommendations for managers regarding the improvement of the purchasing process of business services.

\section{The importance of buying business services}

We are now at the beginning of a new era, the industrial society has become a service society and is on the way to become an information and knowledge society. We can observe that services are bought and consumed more than ever, as a consequence of the present developments (see figure no.1).

\footnotetext{
${ }^{1}$ Fellow of Romanian Academy, Iasi Subsidiary, e-mail: sitarcorina@yahoo.com
} 
Today is an important day and you want to make sure that you wake up on time. Therefore, you have arranged with an operator for a wake up call. After you wake up you pick up the newspaper from your mailbox and you take the breakfast. You read in the newspaper an interesting information about the Stock Exchange and turn on the TV for teletext and morning news.

You take the subway to go to the office because your car is at the garage for repairs and you will need to pick it up later. When you arrive at the office, you read your emails, listen to the messages on your voicemail and check your agenda. At 11o'clock you have an important meeting with an consultant. When he arrives you go in the cafeteria to start the discussion with a cup of coffee. The next meeting is during lunch with a project group. The discussions take places in the company's own restaurant.

You receive the books you ordered from the Internet then you make an important phone call and make a memo on the company's strategy. In the afternoon you arrange a ticket to Paris with a travel agency.

You leave the office a little bit earlier because your daughter has an appointment and you have agreed to babysit your granddaughter. In order to arrive on time you take a taxi and pick up your car from the garage. On the way, you buy a toy and some chocolate to please your granddaughter. For the dinner you order two pizza from a delivery service. When your granddaughter has gone to bed, you use your daughter's computer to do some electronic banking. Late in the evening you drive home, see a movie and go to bed.

Figure no. 1. - A day in the modern service society

Source: Adapted after Axelsson and Wynstra, 2002

This is how it looks like a day for many people in the contemporary society. We don't realize how many services we consume in one day and we don't pay too much attention to the way we purchase these services.

Services begin to play an important role in the social and economical progress of the knowledge based economies. Also in the literature, researchers have noted the important role of the services sector at the economical progress (Gronrros, 1990, Axelsson and Wynstra, 2002).

The importance of the services sector is indicated by the statistics data which indicate that between $60 \%$ and $81 \%$ of the active population is working in this sector (see table no. 1 ). This table provides accurate data about the increasing importance of services in OECD countries. It is obvious the fact that in the developed countries from the European Union around 76,2\% from the active population works in the services sector. In the same time, we can notice that there are big differences between some countries: for example between Germany $(69,9 \%)$ and Netherlands (81,2\%).

Table no 1

Occupancy of the active population in services sector as a percentage of total active population

\begin{tabular}{|l|c|c|c|c|}
\hline \multicolumn{1}{|c|}{ Country } & $\mathbf{1 9 9 7}$ & $\mathbf{2 0 0 7}$ & $\mathbf{2 0 1 0}$ & Change(1997- 2010) \\
\hline France & 69,9 & 73,3 & 75 & 5,1 \\
\hline Germany & 60,2 & 67,9 & 69,9 & 9,7 \\
\hline Japan & 61,6 & 68,4 & 70,6 & 9 \\
\hline Netherlands & 74,1 & 74,7 & 81,2 & 7,1 \\
\hline Sweden & 71,3 & 76 & 77,1 & 5,8 \\
\hline United Kingdom & 71,3 & 76,1 & 78,9 & 7,6 \\
\hline United States & 73,4 & 78,7 & 81,2 & 7,8 \\
\hline
\end{tabular}


We can also notice that in the period 1997-2010, in all the countries the percentage that indicates the occupancy of the active population in services sector increased with at least five percentages. The largest increase was recorded by Germany (9,7\%) and Japan (9\%).

The researchers consider that the statistics don't reflect the true magnitude and dynamic of the services sector. The statistics don't include so called hidden services, such as: finance, accounting, legal services and also the complementary services related to installation, bringing optimal operating capacity, staff training, repairs, etc.

There are several factors behind the development of the services sector but the approaches in the literature are different. Somesan (1997) considers that the strong grow of the service economy is generated by the following factors:

- new technologies of production emerged

- higher complexity of the products

- the strategic importance of the IT technologies

- stiffer international competition.

Baker (1997) has another approach and he considers that there are three important factors that are responsible for the growth of the services sector:

- the technological impact - new technologies have determined the development of services. The volume and the quality of the available services is also increasing and determines an increased demand for services.

- clients specialization - society becomes richer and so important parts of the income is available for the satisfaction of special desires and recreational activities: holidays, dinners at the restaurants, hobbies). This is substantially enhancing the demand for certain services.

- increased competition and new regulations - changing conditions for penetration and maintenance on certain markets and the need to increase competitiveness creates new opportunities for services companies (for example: financial sector, real estate agents).

We consider that besides the factors found in the literature review there is one which has greatly contributed at the growing importance of services sector, namely specialization. Nowadays, organizations are in a continuous process of specialization. Services such as security, cleaning and so on were produced within the organizations and now all these services are purchased from outside from the specialized companies that provide them.

\section{Special issues of the purchasing process of business services}

Many definitions of services can be found in the literature. We choose to focus our attention on the following definition: "a service is a process consisting of a series of more or less intangible activities that normally, but not necessarily always, take place in interactions between customer and service employees and/or physical resources or goods and/or systems of the service provider, which are provided as solutions to customer problem.” (Gronroos, 2000: 46)

Organizations have to buy many business services every day. We mention further some of these business services: accounting services, catering services, cleaning services, insurance services, banking services, advertising services, transport services, training services, logistics services, legal services, etc.

Axelsson and Wynstra (2002) classified business services into the following categories:

- information and communication technology services (all services regarding ICT issues such as hardware implementation, maintenance, telecommunication services);

- financial services (banking, finance, salary administration, insurance);

- facility services (cleaning, catering, security);

- business organization services (management consultancy, environmental consultancy, risk management, accounting and auditing, legal services); 
- transportation and distribution services (warehousing, value added logistics, transportation services);

- research and development technical services (technical maintenance, repairs and assistance, development and engineering).

Purchasing business services has become an important activity also for romanian companies. The amount of money involved in buying business services is raising. Business services present a number of characteristics which makes their purchasing process more difficult. We will focus our attention on the most important characteristics:

1. intangibility

2. impossibility of storage

3. heterogeneity

4. inseparability of production and consumption

\section{Intangibility}

Intangibility is considered to be the fundamental characteristic of business services. This is also a major factor in differentiating services from material goods. This characteristic has two important aspects:

- the physical inability to touch the service

- mental difficulty to imagine the service

Unlike the goods, services cannot be seen, felt, heard and smelled before they are bought. For example, the client of a legal service is not able to know beforehand the results produced by using the legal service that has been bought.

Some buyers of services have the impression that they are exposed to some risks, they are not sure about their choice, they would like some evidence about the quality of services but they cannot obtain them because of the services intangibility. They try to draw conclusions from what it can be seen, from the visible parts of services such as: the place of the service, the employee and their behavior, the price, etc.

The intangibility makes difficult not only the comparison, but also the possibility to have a clear picture about the service. The purchasing decision has to be taken in unknown conditions and becomes stressful for the buyer. It is very important in this case the clear definition of advantages that the buyer will gain by buying the service.

\section{Impossibility of storage}

Unlike the goods, services cannot be stored and inventoried. Therefore, in the services industry, services cannot be stored in order to be used in the high demand periods. Because of their perish ability, services has to be purchased just in time to be consumed. The process of purchasing business services has to be carefully planned to ensure that they are provided at the right time and in the right place.

\section{Heterogeneity}

Heterogeneity is a special characteristic of services which makes them different from goods and does not allow to standardize them. In general, the quality of services is not constant and fluctuates depending on the person who provides the service, the time and the place. That is why it is difficult to predict and ensure the same quality for services in time, because the quality may be affected by the provider performances and by the customer behavior.

The services providers and the customers are well aware of the fact that services have a high degree of uniqueness and in order to reduce and prevent the feeling of dissatisfaction they try to minimize its effects. The provider tries to customize service performance by adapting the service to personal needs, using a differentiated approach for each customer. The customers gather information about the company, about its performance before deciding to buy the service. 


\section{Inseparability of production and consumption}

This is another typical characteristic of business services. Unlike the goods which can be produce in a period and sold and consumed in another period and space, services cannot be stored and transported. For services, their provision and consumption are inseparable and simultaneously.

Because of production and consumption simultaneity, the quality of services cannot be appreciated before their purchasing. There are services for which it is difficult to appreciate the quality even after their consumption (for example: the results of the consultancy services can be appreciated only in time). This difficulty to evaluate the services quality involves a higher risk in the purchasing process of services than in purchasing goods.

Wittreicht (2000) considers that the rules that are applied when goods are purchased cannot be used for buying business services. This happens because of the particularities of the purchasing process of services. The most important particularities of the purchasing process of business services are:

1. identifying the content of business service

An important problem which appears in case of business services is that the service does not exist in the moment when it is bought. Therefore, the customers can have difficulties in defining and evaluating the content of the services. This particularity of services makes more difficult the first phase of the purchasing process: the specification of needs.

2. defining the quality of business services

The process of producing services consists in more repetitive activities which take place in close collaboration between buyer and supplier. If any problem appears in this process, there will also problems in services delivery. That is why the initial evaluation of the suppliers is very important for the buying organization. It is important to asses also the effort done by the buying organization in order to maintain a beneficial relation with the suppliers. For example, in the case of the managerial consultancy customers will be concerned about selecting a consultancy firm which is well known in order to be sure about the quality of the consultancy services.

3. difficulties related to the price of business services

Sometimes it is difficult to notice the connection between the price and the value of a service.

This fact can create difficulties in the second and third phase of the purchasing process: selection of suppliers and negotiating the contracts.

4. the impossibility to store business services

Because of the impossibility to store business services, it is important for organizations to asses

properly their needs in order to make sure that they will have enough services when they need them. It is important also for suppliers to adapt their service offerings with the moment when the customers want the services.

\section{Findings from empirical examples}

In the attempt to discover how are things in practice regarding to the purchasing process of business services we made three in-depths interviews. With the interviews we wanted to find out the answers to the following questions:

- Is purchasing recognized as a strategic function of the organization?

- Who buys business services in the organization?

- Are any policies and procedures set for purchasing process of business services?

- Is top management interested in purchasing process of business services?

- If the purchasing process of business services is controlled and evaluated by top management?

- Etc. 
The interviews were made with managers of three different organizations from Maramures county:

- SC Adiss SA (Baia Mare)

- SC Faimar SA (Baia Mare)

- SC Amisa SA (Baia Mare).

Faimar SA is an organization from the ceramic industry and it produces a wide range of ceramic articles. The company has 350 employees and produces a wide range: household and artistic ceramics (table, vase). Around 85\% from the turnover is obtained from export. At the interview we discussed with the general manager and with the manager of the purchasing and transportation department.

Adiss SA is an organization that has been founded in 1992 and is dealing with wastewater treatment and its main areas of activity are: design, technology and detail engineering, production and delivery of equipment. Adiss is one of the leaders in Romania and has 92 employees. At the interviews we discussed with the general manager and with the manager of the purchasing department.

Amisa SA designs, manufactures and sells construction works in high efficiency conditions. The company performs in the followings fields:

- construction and installation (industrial and civil construction, plumbing, electrical, automation)

- electrical network (network extensions and repairs of high and low voltage electrical, repair public lighting networks)

- $\quad$ networks with gas (gas regulating and measuring stations, gas pipe repairs)

- mines closures

Amisa SA has 221 employees and has experience in the construction field for over 45 years.

We used focused (semi-structured) interviews in order to collect qualitative data from the managers of the selected organizations. We choose to use this method because it allows the respondent the time and scope to talk about their opinion on a particular subject. During the interview, we used open-ended questions, some suggested by use and some arise naturally during the interview.

The interview had two parts. The first part refers to the following aspects:

- general data about the organization (number of employers, total revenue, etc.)

- organization and role of the purchasing department

- the recognition of the purchasing function into the company

The second part contains questions about:

- phases of the purchasing process of business services

- $\quad$ evidence of services purchased (money spent, suppliers involved, etc.)

- evaluation and control from manager over the purchasing process of the business services.

We used the method of focused interviews because it provides a depth of information through the use of open-ended questions and it allows the respondent to talk freely about issues and does not constrain their responses.

The summarized results of the interviews are presented in table no. 2 .

As you can see in the table no. 2 the purchasing process of business services is best organized at Faimar SA and Adiss SA. The managers of these companies recognize the strategic importance of the purchasing function. At these companies a clear methodology for the purchasing process of business services has been set by management. Also, general manager is interested in the purchasing of services and knows what is going on in the company: who is buying what? from which supplier? .This fact is obvious in the way that the process of buying services is organized and controlled. The management of these companies evaluate and control periodically the purchasing process of business services. 
At Amisa SA purchasing of business services is not considered a priority neither for general manager, nor for manager of the Purchasing Department. This can be observed in the way that purchasing process is organized. In this case, there are not clear define procedure for the purchasing process of services and it is not clear who is responsible for the purchasing of each type of business service. The main criterion used for the selection of suppliers is the smallest price and there is no cleared responsibility defined for the phases of monitoring and evaluating the purchasing process of business services. The management of Amisa SA does not control and evaluate periodically the purchasing process of business services.

Table no.2.

Summarized results from the interviews

\begin{tabular}{|c|c|c|c|}
\hline & SC Adiss SA & SC Faimar SA & SC Amisa SA \\
\hline $\begin{array}{l}\text { Recognition of the strategic } \\
\text { importance of the purchasing } \\
\text { function }\end{array}$ & Yes & Yes & No recognition \\
\hline $\begin{array}{l}\text { Management support for } \\
\text { purchasing business services }\end{array}$ & Yes & Yes & No management support \\
\hline $\begin{array}{l}\text { Policies and procedures for } \\
\text { purchasing business services }\end{array}$ & $\begin{array}{l}\text { Clear policies and } \\
\text { procedures }\end{array}$ & $\begin{array}{l}\text { Clear policies and } \\
\text { procedures }\end{array}$ & $\begin{array}{l}\text { Does not exist special } \\
\text { policies and procedures } \\
\text { for purchasing business } \\
\text { services }\end{array}$ \\
\hline $\begin{array}{l}\text { Selection and evaluation of } \\
\text { suppliers }\end{array}$ & $\begin{array}{c}\text { Rigorous process of } \\
\text { selection and evaluation of } \\
\text { suppliers }\end{array}$ & $\begin{array}{l}\text { The existence of a logical } \\
\text { framework for evaluation } \\
\text { and selection of suppliers }\end{array}$ & $\begin{array}{l}\text { The smallest price is the } \\
\text { main criteria for selecting } \\
\text { the suppliers }\end{array}$ \\
\hline Contracting phase & $\begin{array}{l}\text { Purchasing department } \\
\text { responsibility }\end{array}$ & $\begin{array}{l}\text { Purchasing department } \\
\text { responsibility }\end{array}$ & $\begin{array}{l}\text { No cleared responsibility } \\
\text { defined }\end{array}$ \\
\hline Ordering phase & $\begin{array}{l}\text { Purchasing department } \\
\text { responsibility }\end{array}$ & $\begin{array}{l}\text { Purchasing department } \\
\text { responsibility }\end{array}$ & Internal customers \\
\hline Monitoring and evaluating & $\begin{array}{l}\text { Purchasing department } \\
\text { responsibility }\end{array}$ & $\begin{array}{l}\text { Purchasing department } \\
\text { responsibility }\end{array}$ & $\begin{array}{c}\text { No cleared responsibility } \\
\text { defined }\end{array}$ \\
\hline $\begin{array}{lcr}\begin{array}{l}\text { Evidence } \\
\text { purchased }\end{array} & \text { of } & \text { services } \\
\text { (money } & \text { spent, } \\
\text { suppliers involved, etc.) }\end{array}$ & Clear evidence & Clear evidence & No evidence \\
\hline $\begin{array}{l}\text { Evaluation and control from } \\
\text { management }\end{array}$ & Periodically & Periodically & Rarely \\
\hline $\begin{array}{l}\text { Centralization/Decentralization } \\
\text { of purchasing process of } \\
\text { business services }\end{array}$ & $\begin{array}{l}\text { Wants to centralize the } \\
\text { entire purchasing process } \\
\text { of business services } \\
\text { through purchasing } \\
\text { department }\end{array}$ & $\begin{array}{l}\text { Centralized purchasing } \\
\text { process of business } \\
\text { services through } \\
\text { purchasing department }\end{array}$ & $\begin{array}{l}\text { Mix of centralized and } \\
\text { decentralized }\end{array}$ \\
\hline
\end{tabular}

\section{Conclusion}

The particularities of business services make more difficult some phases of the purchasing process. So, the difficulties for identifying the content and defining the quality of business services create some difficulties in the first phases of the purchasing process: the specification of the needs and the selection of the suppliers. The difficulties in identifying the connection between the price and the value of a service makes more difficult the selection and negotiation with the suppliers. The impossibility to store and reception business services causes changes in the standard reception procedure.

Business services have a number of characteristics which may contribute to the fact that they are purchased outside of the Purchasing Department:

- wide range of services which are often coupled with an even larger numbers of suppliers;

- relative high frequency of initial purchasing activities; 
- high level of internal end-user involvement, especially in the initial steps of the purchasing process.

Also, purchasing of business services is not seen by managers as a necessity, compared to the purchasing of goods and raw materials for the primary process. As a consequence of this undervaluation, structural attention and management of purchasing of services is not considered as a means for improving effectiveness and reducing expenditures. Because of the lack of clear and direct

insight in the size and contents of the purchasing volume of business services, managers are missing opportunities for adding value to their organizations.

Because of these particularities of the purchasing process, managers should pay more attention to the purchasing process of business services. They should create special policies and procedures for the purchasing process of business services which can improve the efficiency and effectiveness of the buying process. Managers should monitor and evaluate periodically the purchasing of business services in order to stimulate better results. Only in this way the purchasing process of business services will be able to help to increase the organization profitability.

\section{Acknowlegment}

This paper was made within "The Knowledge Based Society Project" supported by the Sectoral Operational Programme Human Resources Development (SOP HRD), financed from the European Social Fund and by the Romanian Government under the contract number POSDRU ID 56815.

\section{References}

1. Axelsson B., Wynstra F., 2000. Companies buy services, don't they?, Proceedings $9^{\text {th }}$ IPSERA Conference, London, Ontario, Canada, 42-53.

2. Axelsson B., Wynstra F., 2002. Buying business services, Chichester: Wiley.

3. Atkinson W., 2000. Buyers are involved 'cradle to grave', Purchasing Magazine, October 19, 75-77.

4. Ford D., 2002. Understanding business marketing and purchasing, third edition, Thomson Learning.

5. Gronroos C., 1990. Service management and marketing, Massachusetts, Toronto, Lexington Books.

6. Gronroos C., 2000. Service Management and marketing: a customer relationship management approach ( $2^{\text {nd }}$ edition), Wiley, Chichester.

7. Nowikow C., 1999. Revolution, or evolution, Supply Management, September 23, 26-32.

8. OECD Statistics http://stats.oecd.org/index.aspx?queryid=24862 (17.09.2011)

9. Porter A. M., 1999. Taking control of 'indirect' corporate spending, Purchasing Magazine, September 2, 55-60.

10. Richardson G.B., 1999. What can an economist learn from managing a business? , In: Dow, S.C and Earl, P.E. (Eds). Economic Organization and Economic Knowledge. Essays in Honour of Brian J. Loasby. Vol. I, Cheltenham, 239-254.

11. Simon H.A., 1976. Administrative behavior. A study of decision-making processed in administrative organization, New York, The Free Press.

12. Smith A., 1999 (first published 1776). The Wealth of Nations. Books I-III, London, Penguin Books.

13. Somesan C., 1997. Marketingul serviciilor de afaceri, Cluj Napoca, Sincron.

14. Telgen J., de Boer L., 1995. Developments in purchasing of non-production items, Proceedings $4^{\text {th }}$ IPSERA Conference, Eindhoven, 1-8.

15. van der Valk W., Rozemeijer F., 2009. Buying business services: towards a structured service purchasing process, Journal of Services Marketing, Vol. 23 Issue 1, 3 - 10

16. Weele A.J., van and Rozemeijer F., 1996. Revolution in purchasing: building competitive power through pro-active purchasing, Eindhoven, Philips Electronics. 